\title{
Expression of NF-кB and PTEN in osteosarcoma and its clinical significance
}

\author{
TENG GONG ${ }^{1,2}$, XUETAO $\mathrm{SU}^{3}$, QUN XIA ${ }^{3}$, JINGGUI WANG $^{3}$ and SHILIAN KAN ${ }^{1}$ \\ ${ }^{1}$ Department of Spinal Surgery, Tianjin Hospital, Tianjin 300211; ${ }^{2}$ Post-Doctoral Research Station, \\ Tianjin Medical University, Tianjin 300070; ${ }^{3}$ Department of Orthopaedic Surgery, The Affiliated Hospital \\ of Logistics College of Chinese People's Armed Police Forces, Tianjin 300162, P.R. China
}

Received May 29, 2017; Accepted September 8, 2017

DOI: $10.3892 / \mathrm{ol} .2017 .6972$

\begin{abstract}
We investigated the role of nuclear factor $-\kappa B$ $(\mathrm{NF}-\kappa \mathrm{B})$ and phosphatase and tensin homolog deleted in chromosome 10 (PTEN) in the pathogenesis of osteosarcoma and its relationship with prognosis. Immunohistochemical method was used to detect the expression of NF- $\kappa \mathrm{B}$ and PTEN in osteosarcoma and adjacent tissues. RT-PCR was used to detect the expression of NF- $\kappa \mathrm{B}$ and PTEN mRNA in osteosarcoma and adjacent tissues. Western blotting was used to detect the expression of NF- $\mathrm{KB}$ and PTEN in osteosarcoma and adjacent tissues and compare their differences. The expression of NF- $\mathrm{KB}$ and PTEN was detected in osteosarcoma and adjacent tissues. The positive rate of $N F-\kappa B$ was 75.3 and $32.9 \%$, respectively; while the positive rate of PTEN was 67.1 and $90.4 \%$, respectively. The positive expression of $\mathrm{NF}-\kappa \mathrm{B}$ and PTEN was statistically significant. There was a negative correlation between NF- $\mathrm{B}$ and PTEN expression $(\mathrm{r}=-0.502, \mathrm{p}<0.05)$. The positive and negative expression of $\mathrm{NF}-\kappa \mathrm{B}$ and PTEN was statistically significant for the five-year survival $(\mathrm{p}<0.05)$. At gene and protein level, osteosarcoma tissues had higher expression of NF- $\kappa \mathrm{B}$, and lower expression of PTEN, which was significantly different from the adjacent tissues. In osteosarcoma, $\mathrm{NF}-\kappa \mathrm{B}$ is highly expressed, but PTEN is expressed at low level, and the two are negatively correlated. This is of great significance for the early diagnosis of osteosarcoma and prognosis.
\end{abstract}

\section{Introduction}

As one of the more common malignant bone tumor, osteosarcoma has high degree of malignancy, and relatively poor prognosis (1). The pathogenesis and development process has

Correspondence to: Dr Xuetao Su, Department of Orthopaedic Surgery, The Affiliated Hospital of Logistics College of Chinese People's Armed Police Forces, 220 Chenglin Road, Dongli, Tianjin 300162, P.R. China

E-mail: spfd97@163.com

Key words: osteosarcoma, nuclear factor- $\kappa \mathrm{B}$, phosphatase and tensin homolog deleted in chromosome 10 not yet been studied fully, and the current clinical diagnosis of osteosarcoma lacks more specific indicators (2). PTEN as a tumor suppressor gene, is associated with the occurrence and development of a variety of malignant tumors $(3,4)$. Overexpression of $\mathrm{NF}-\kappa \mathrm{B}$ is associated physiologically and pathologically with many tumors, and is a bi-directional regulatory factor (5-7). There are few studies on the expression and correlation of PTEN and $\mathrm{NF}-\kappa \mathrm{B}$ in osteosarcoma to date. The purpose of this study is to use immunohistochemical method to detect the expression of PTEN and $\mathrm{NF}-\kappa \mathrm{B}$ in tumor tissues, explore their expression changes at genes and protein levels, and analyze statistically the expression of both and the prognosis of patients, to explore their expression correlation in osteosarcoma and the potential use in clinical diagnosis of osteosarcoma.

\section{Materials and methods}

\section{Materials}

Experimental materials. Pathologically confirmed osteosarcoma tumor tissues ( 73 cases) and adjacent tissues ( 73 cases) were selected. All patients signed an informed consent form. The osteosarcoma tissue and adjacent tissues were treated with paraffin embedding, and then paraffin sectioned with a thickness of $\sim 4 \mu \mathrm{m}$. The patients with osteosarcoma were follow-up for 5-years.

Reagents. Rabbit antihuman nuclear factor $-\kappa \mathrm{B}(\mathrm{NF}-\kappa \mathrm{B})$ monoclonal antibody (Beijing Dingguo Changsheng Biotechnology Co.,Ltd., Beijing, China) rabbit anti-human phosphatase and tensin homolog deleted in chromosome 10 (PTEN) polyclonal antibody, rabbit anti-human glyceraldehyde 3-phosphate dehydrogenase (GAPDH) polyclonal antibody (cat. no. SPC-1303, SPC-1331 and SPC-689; StressMarq Biosciences Inc., Victoria, BC, Canada), DAB coloring reagent (Shanghai Runwell Technology Co., Ltd., Shanghai, China), citrate buffer powder (Shanghai X-Y Biotechnology Co., Ltd., Shanghai, China), reverse transcription kit (GeneCopoeia, Rockville, MD, USA), real-time fluorescence quantitative PCR and Western Blot test kit (Shanghai Biological BestBio Bebo, Shanghai, China), goat anti-rabbit IgG secondary polyclonal antibody (cat. no. ab150077; Abcam, Cambridge, UK), BCA protein quantitative kit (Nanjing SenBeiJia Biotechnology Co., Ltd., Nanjing, China). 


\section{Experimental methods}

Immunohistochemical staining. The paraffin sections were subjected to dewaxing and then washed with phosphate-buffered saline. To reduce the nonspecific background staining caused by endogenous peroxidase, blocking was continued for $20 \mathrm{~min}$ in the blocking buffer, then blocked in $10 \%$ serum for $10 \mathrm{~min}$ at room temperature, and incubated overnight at $4^{\circ} \mathrm{C}$ with the addition of primary antibody dilution buffer (rabbit anti-human NF- $\mathrm{B}$ monoclonal antibody and PTEN polyclonal antibody, 1:50 dilution). It was washed with phosphate buffer solution, adding the goat anti-rabbit IgG secondary polyclonal antibody dilution buffer (1:50 dilution) and incubated at room temperature for $30 \mathrm{~min}$. It was washed again with phosphate buffer, and then incubated with Streptavidin antibiotic proteinperoxidase solution at room temperature for $30 \mathrm{~min}$, washed with phosphate buffer solution, colored with DAB, washed with distilled water, stained and sealed.

Evaluation of results. One hundred cells were randomly selected to observe the visual field under a light microscope, and the average number of cells in the field of view was obtained as the positive cells expressing the protein in the tissue. PTEN staining was mainly located in the cytoplasm, while the positive expression of $\mathrm{NF}-\kappa \mathrm{B}$ was mainly located in the nucleus. Depth score: scores 0 to 2, was assigned for no coloring, weak coloring and strong coloring, respectively. Cells stained positive score: 1 to $25 \%$ was recorded as 1, 26 to $50 \%$ as 2,51 to $75 \%$ as 3,76 to $100 \%$ as 4 . The scores of the depth score and the positive rate were multiplied, 1 to 2 were negative, and 3 to 8 were positive.

Real-time PCR method to determine the expression of $N F-\kappa B$ and PTEN $m R N A$. Total RNA was extracted from both tissues and the concentration and purity were determined. Table I shows the primer sequence used in the synthesis of $\mathrm{NF}-\kappa \mathrm{B}$ and PTEN gene amplification by Nanjing CoBioer Biotechnology Co., Ltd. (Nanjing, China). Reverse transcription synthesis of cDNA, reaction system $20 \mu \mathrm{l}$.

PCR reaction system: $25 \mu \mathrm{l}$, reaction conditions: $95^{\circ} \mathrm{C}$ $10 \mathrm{~min}, 95^{\circ} \mathrm{C} 30 \mathrm{sec}$, and $59.4^{\circ} \mathrm{C} 30 \mathrm{sec}, 40$ cycles, $95^{\circ} \mathrm{C} 15 \mathrm{sec}$, and maintained at $65^{\circ} \mathrm{C}$. With GAPDH as the internal control, RT-PCR instrument automatically calculated the NF- $\kappa \mathrm{B}$ and PTEN mRNA relative expression.

Western blot assay for detection of protein. The total protein in the two tissues was extracted according to the instructions in the tissue total protein extraction kit. The concentration of the extracted protein was determined by BCA protein assay, and stored at $-70^{\circ} \mathrm{C}$. Sodium dodecyl sulfate-polyacrylamide gel electrophoresis (SDS-PAGE) was performed on $10 \%$ separation gel and 5\% concentrated gel. The gel position of the two proteins was selected according to the marker strip. After transmembrane, the PVDF membrane was washed with $1 \mathrm{X}$ TBST solution for $5 \mathrm{~min}, 5 \%$ nonfat dry milk blocking at room temperature (1:1,000 dilution) for $1 \mathrm{~h}, 1 \mathrm{X}$ TBST solution for $1 \mathrm{~h}, 1 \mathrm{X}$ TBST solution for $1 \mathrm{~h}$, 1X TBST solution $5 \mathrm{~min}$, total cleaning 3 times. Anti-dark drop ECL luminescent liquid, dark environment for 2 min for development. Finally, the Multi Gauge Ver. 3.0 imaging system was scanned, and ImageJ professional image analysis software (National Institutes of Health, Bethesda, MD, USA)
Table I. NF- $\kappa$ B and PTEN gene amplification primer.

\begin{tabular}{lcc}
\hline Gene & Primer sequence \\
\hline NF-кB & F: 5'-TACCCTGAGGCTATAACTC-3' \\
& R: 5'-GACACTTGATAAGGCTTTG-3' \\
PTEN & F: 5'-AGTTCCCTCAGCCGTTACCT-3' \\
& R: 5'-ATTTGACGGCTCCTCTACTG-3' \\
GAPDH & F: 5'-TGGGTGTGAACCACGAGAA-3' \\
& R: 5'-GGCATGGACTGTGGTCATGA-3'
\end{tabular}

NF- $\kappa \mathrm{B}$, nuclear factor- $\kappa \mathrm{B}$; PTEN, phosphatase and tensin homolog deleted in chromosome 10; GAPDH, glyceraldehyde 3-phosphate dehydrogenase; F, forward; R, reverse.

Table II. PTEN expression comparison in both tissues.

\begin{tabular}{|c|c|c|c|c|c|c|}
\hline \multirow[b]{2}{*}{$\begin{array}{l}\text { Arm } \\
\text { P-value }\end{array}$} & \multirow{2}{*}{$\begin{array}{l}\text { No. of } \\
\text { cases }\end{array}$} & \multicolumn{2}{|c|}{ PTEN } & \multirow{2}{*}{$\begin{array}{c}\text { Positive } \\
\text { rate } \%\end{array}$} & \multirow[b]{2}{*}{$\chi$} & \multirow[b]{2}{*}{2} \\
\hline & & + & - & & & \\
\hline Osteosarcoma & 73 & 49 & 24 & 67.1 & 31.02 & $<0.05$ \\
\hline Adjacent tissues & 73 & 66 & 7 & 90.4 & & \\
\hline
\end{tabular}

PTEN, phosphatase and tensin homolog deleted in chromosome 10.

was used for image analysis and the absorbance value was recorded.

Statistical analysis. The statistical software SPSS 17.0 (Beijing Xinmei Jiahong Technology Co., Ltd., Beijing, China) was used in this study for data analysis. The correlation between the expression of NF- $\mathrm{BB}$ and PTEN was tested by Spearman's method, using $\chi^{2}$ to test the difference of positive rates between arms. The survival analysis was analyzed by GraphPad Prism5 software (GraphPad Software Inc., La Jolla, CA, USA). The difference was considered statistically significant when $\mathrm{p}<0.05$.

\section{Results}

The expression of PTEN and NF- $\mathrm{B} B$ in osteosarcoma tissues and adjacent tissues. The immunohistochemical staining showed that PTEN had more positive expression granules in osteosarcoma tissues, while in adjacent tissues, PTEN showed diffuse granule-like expression with expression level significantly higher than that of osteosarcoma tissues. The notable difference of the positive expression rate of PTEN in osteosarcoma tissues and adjacent tissues was statistically significant $(\mathrm{p}<0.05)$ (Fig. 1).

Among 73 cases of osteosarcoma tissues, 49 cases were positive in PTEN expression, with positive rate of $67.1 \%$; while in adjacent tissues, 66 cases were positive in PTEN expression, with positive rate of $90.4 \%$ (Table II). 


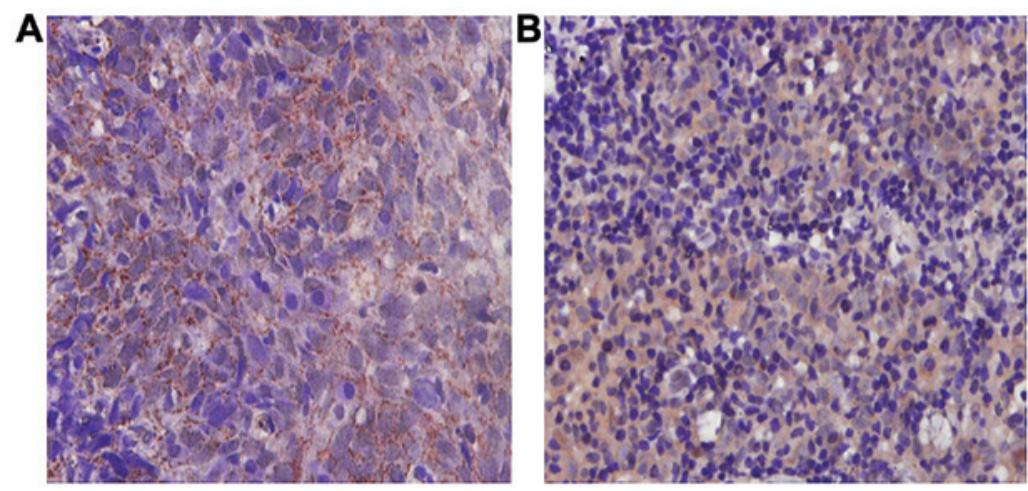

Figure 1. Immunohistochemical expression of phosphatase and tensin homolog deleted in chromosome 10 (PTEN) in osteosarcoma tissues and adjacent tissues. Immunohistochemical staining of the two types of tissues. The expression of PTEN in the adjacent tissues was higher than that in the osteosarcoma tissues. (A) Osteosarcoma tissues, (B) adjacent tissues.
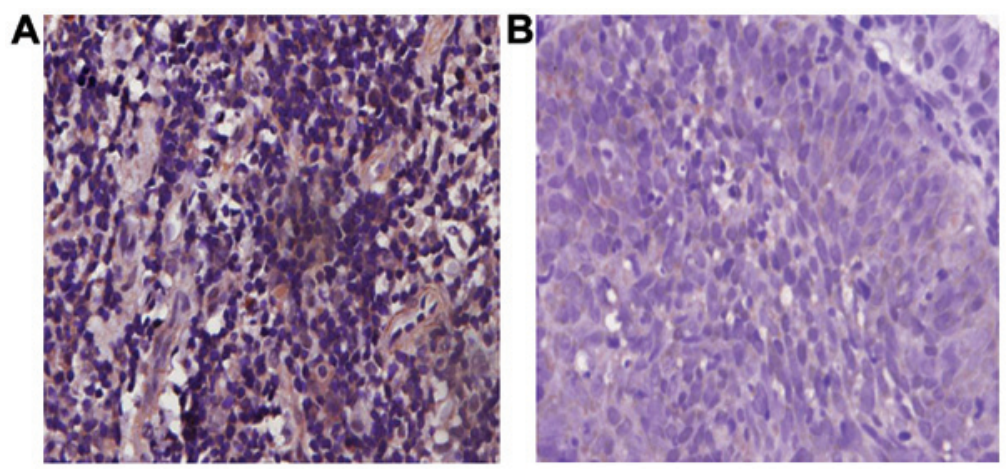

Figure 2. Immunohistochemical expression of nuclear factor- $\kappa \mathrm{B}(\mathrm{NF}-\kappa \mathrm{B})$ in osteosarcoma tissues and adjacent tissues. Immunohistochemical staining of the two tissues. The NF- $\kappa$ B in osteosarcoma tissue had significantly positive expression of granules, while the presence of NF- $\kappa \mathrm{B}$ in the adjacent tissue was not obvious. (A) Osteosarcoma tissues, (B) adjacent tissues.

Table III. Comparison of NF-kB expression in both tissues.

\begin{tabular}{|c|c|c|c|c|c|c|}
\hline \multirow[b]{2}{*}{ Arm } & \multirow[b]{2}{*}{$\begin{array}{l}\text { No. of } \\
\text { cases }\end{array}$} & \multicolumn{2}{|c|}{ NF-кB } & \multirow[b]{2}{*}{$\begin{array}{l}\text { Positive } \\
\text { rate\% }\end{array}$} & \multirow[b]{2}{*}{$\chi^{2}$} & \multirow[b]{2}{*}{ P-value } \\
\hline & & + & - & & & \\
\hline Osteosarcoma & 73 & 55 & 18 & 75.3 & 40.57 & $<0.01$ \\
\hline Adjacent tissues & 73 & 24 & 49 & 32.9 & & \\
\hline
\end{tabular}

$\mathrm{NF}-\kappa \mathrm{B}$, nuclear factor- $\kappa \mathrm{B}$.

Immunohistochemical staining showed that NF- $\kappa \mathrm{B}$ had a significant positive expression of granulocyte in osteosarcoma tissues, while NF- $\kappa \mathrm{B}$ expression was not obvious in adjacent tissues. The positive expression of NF- $\mathrm{KB}$ in osteosarcoma tissues was statistically significantly higher than that in adjacent tissues ( $\mathrm{p}<0.05)$ (Fig. 2).

Out of 73 osteosarcoma tissues, 53 were positive in NF-kB expression. The positive rate was $75.3 \%$; while 24 adjacent tissues were positive in NF- $\mathrm{KB}$ expression. The positive rate was $32.9 \%$ (Table III).

Correlative analysis of PTEN and NF- $\kappa B$ expression in osteosarcoma. Out of 73 osteosarcoma tissues, 53 were positive in NF- $\mathrm{BB}$ expression. Among them, 16 cases were also positive
Table IV. Correlation of NF- $\mathrm{kB}$ and PTEN expression.

\begin{tabular}{lcrcrr}
\hline & \multicolumn{2}{c}{ PTEN } & & & \\
\cline { 2 - 5 } NF-kB & + & - & Total & r-value & P-value \\
\hline+ & 16 & 39 & 55 & -0.502 & $<0.05$ \\
- & 14 & 4 & 18 & & \\
Total & 30 & 43 & 73 & & \\
\hline
\end{tabular}

$\mathrm{NF}-\kappa \mathrm{B}$, nuclear factor- $\kappa \mathrm{B}$; PTEN, phosphatase and tensin homolog deleted in chromosome 10.

for PTEN, at a rate of $29.1 \%$. The statistical analysis shows a negative correlation between NF- $\kappa B$ and PTEN ( $r=-0.502$, $\mathrm{p}<0.05$ ) (Table IV and Fig. 3).

Detecting NF- $\kappa B$ and PTEN mRNA expression by RT-PCR. The relative expression of NF- $\mathrm{KB}$ mRNA in osteosarcoma tissues $(52.9 \pm 4.17)$ was significantly higher than that in adjacent tissues $(39.2 \pm 5.94)$, the difference was statistically significant $(\mathrm{p}<0.05)$; and the relative expression of PTEN mRNA $(59.3 \pm 3.19)$ was significantly lower than that of adjacent tissues $(91.4 \pm 5.82)$, and the difference was statistically significant $(\mathrm{p}<0.05)$ (Table V and Figs. 4 and 5). 
Table V. The relative expression of NF- $\mathrm{B}$ and PTEN mRNA.

\begin{tabular}{lcc}
\hline Arm & NF- $\kappa B$ & PTEN \\
\hline Osteosarcoma & $52.9 \pm 4.17^{\mathrm{a}}$ & $59.3 \pm 3.19^{\mathrm{c}}$ \\
Adjacent tissues & $39.2 \pm 5.94^{\mathrm{b}}$ & $91.4 \pm 5.82^{\mathrm{d}}$ \\
P-values & $<0.05$ & \\
\hline
\end{tabular}

Comparison of a and $\mathrm{b}, \mathrm{p}<0.05$; comparison of $\mathrm{c}$ and $\mathrm{d}, \mathrm{p}<0.05$. PTEN, phosphatase and tensin homolog deleted in chromosome 10; $\mathrm{NF}-\kappa \mathrm{B}$, nuclear factor- $\kappa \mathrm{B}$.

Table VI. Expression of NF-кB and PTEN protein.

\begin{tabular}{lcc}
\hline Arm & NF- $\kappa \mathrm{B}$ & PTEN \\
\hline Osteosarcoma & $0.872 \pm 0.015^{\mathrm{a}}$ & $1.383 \pm 0.047^{\mathrm{c}}$ \\
Adjacent tissues & $0.403 \pm 0.008^{\mathrm{b}}$ & $1.902 \pm 0.064^{\mathrm{d}}$ \\
P-values & $<0.05$ & \\
\hline
\end{tabular}

Comparison of a and $\mathrm{b}, \mathrm{p}<0.05$; comparison of $\mathrm{c}$ and $\mathrm{d}, \mathrm{p}<0.05$. PTEN, phosphatase and tensin homolog deleted in chromosome 10; $\mathrm{NF}-\kappa \mathrm{B}$, nuclear factor $-\kappa \mathrm{B}$.

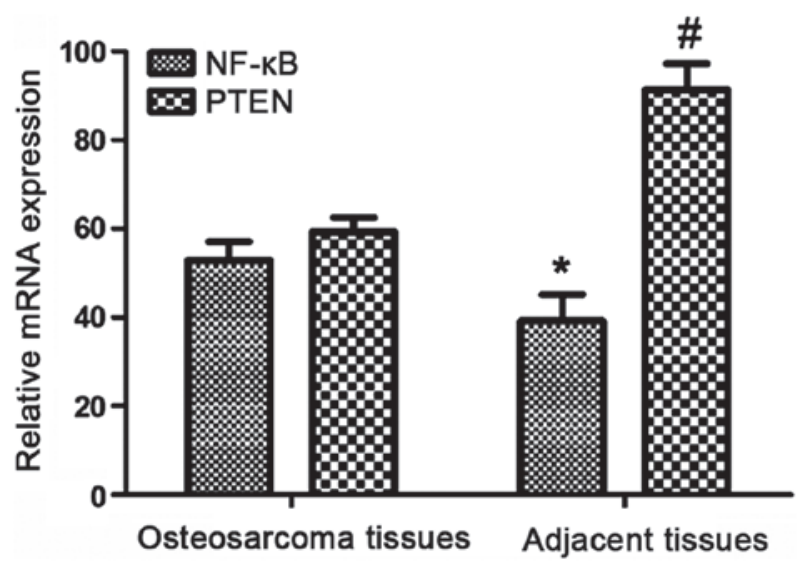

Figure 3. Relative expression of nuclear factor- $\mathrm{\kappa}$ (NF- $\mathrm{kB})$ and phosphatase and tensin homolog deleted in chromosome 10 (PTEN) mRNA. " $\mathrm{p}<0.05$; ${ }^{\#} \mathrm{p}<0.05$.

Detecting $N F-\kappa B$ and PTEN mRNA expression by western blot method. The western blot test indicates the expression of $\mathrm{NF}-\kappa \mathrm{B}$ protein in osteosarcoma tissues was higher $(0.872 \pm 0.015)$, and the expression of $\kappa \mathrm{B}$ in adjacent tissues was lower $(0.403 \pm 0.008)$. The expression of PTEN protein was lower in osteosarcoma tissues $(1.383 \pm 0.047)$, and higher in adjacent tissues $(1.902 \pm 0.064)$. The difference in expression between the two proteins was statistically significant $(\mathrm{p}<0.05)$ (Table VI).

Prognosis of $N F-\kappa B$ and PTEN expression. The survival rate of patients with $N F-\kappa B$ and PTEN positive and negative expression was statistically analyzed. Survival analysis using statistical software showed, the survival rate of those with

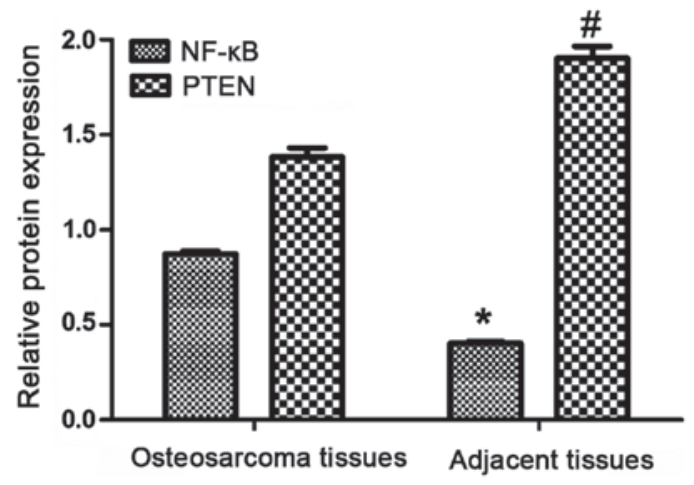

Figure 4. Expression of nuclear factor $-\kappa \mathrm{B}(\mathrm{NF}-\kappa \mathrm{B})$ and phosphatase and tensin homolog deleted in chromosome 10 (PTEN) protein. ${ }^{*} \mathrm{p}<0.05 ;{ }^{\#} \mathrm{p}<0.05$.

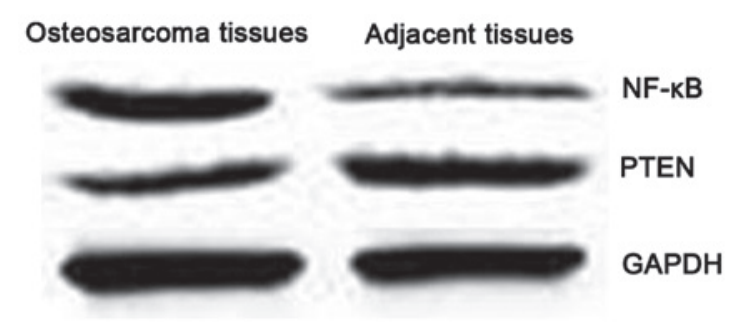

Figure 5. Western blot detection of nuclear factor- $\kappa \mathrm{B}(\mathrm{NF}-\kappa \mathrm{B})$ and phosphatase and tensin homolog deleted in chromosome 10 (PTEN). In osteosarcoma tissues, $\mathrm{NF}-\kappa \mathrm{B}$ expression is higher, $\mathrm{PTEN}$ expression is lower.
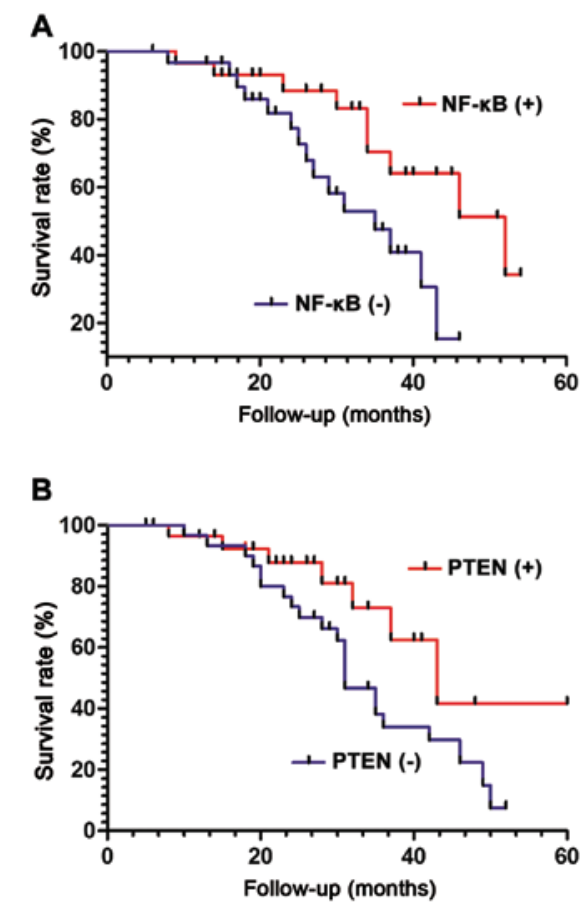

Figure 6. The survival curves of patients with positive and negative expression of nuclear factor- $\kappa \mathrm{B}(\mathrm{NF}-\kappa \mathrm{B})$ and phosphatase and tensin homolog deleted in chromosome 10 (PTEN). The 5-year survival rate was higher for osteosarcoma patients with negative expression of $\mathrm{NF}-\kappa \mathrm{B}$ and positive expression of PTEN.

$\mathrm{NF}-\kappa \mathrm{B}$ positive expression was lower than that of negative expression $\left(\chi^{2}=8.014, \mathrm{p}<0.05\right)$ (Fig. 6A). However, the 5-year survival of patients with PTEN positive expression was signifi- 
cantly higher than that of negative expression. The result was statistically significant $\left(\chi^{2}=7.625, \mathrm{p}<0.05\right)$ (Fig. 6B).

\section{Discussion}

Osteosarcoma is a type of malignant tumor occurring more frequently in adolescents. Osteosarcoma is developed from the interstitial cell line, with strong infiltration and transfer capacity (8-10) PTEN is a tumor suppressor gene with phosphatase activity (11) and it has been reported that PTEN expression is reduced in a variety of human malignancies, such as breast cancer (12) and prostate cancer (13). PTEN has many important functions in the body, such as the inhibition of cell growth and differentiation (14) and promotion of cell apoptosis (15), making it one of the most noticeable tumor suppressor genes after the $\mathrm{p} 53$ gene. $\mathrm{NF}-\kappa \mathrm{B}$ is a transcription factor with a two-way transcriptional regulation that plays an important role in many pathophysiological processes (16-18). Loftus et al (19) reported a significant increase in $\mathrm{NF}-\kappa \mathrm{B}$ p65 expression in hepatocellular carcinoma. The study by Lu et al (20) showed that the expression of $\mathrm{NF}-\kappa \mathrm{B}$ protein in osteosarcoma negative correlates with the apoptotic index of osteosarcoma, and significantly inhibited the apoptosis of osteosarcoma cells. However, reports on the correlation of $\mathrm{NF}-\kappa \mathrm{B}$ expression and PTEN in osteosarcoma are scarce.

Immunohistochemical method was used in this study. the study results indicated that in osteosarcoma tissues, the positive expression rate of PTEN was significantly lower than that in the adjacent tissues, and the positive expression rate of $\mathrm{NF}-\kappa \mathrm{B}$ was significantly higher. The difference between the two are statistically significant $(r=-0.502, p<0.05)$. Therefore, we hypothesized that the decrease of PTEN elevated the expression of NF- $\kappa \mathrm{B}$ through certain mechanism; or the increased expression of $\mathrm{NF}-\kappa \mathrm{B}$ leads to decreased expression of PTEN through certain mechanism. In the osteosarcoma tissues and the adjacent tissues, the mRNA expression of $N F-\kappa B$ was $52.9 \pm 4.17$ and $39.2 \pm 5.94$, respectively; the mRNA expression of PTEN was 59.3 \pm 3.19 and 91.4 \pm 5.82 , respectively. The difference in expression of NF- $\kappa \mathrm{B}$ and PTEN mRNA was statistically significant $(\mathrm{p}<0.05)$. The expression of $N F-\kappa B$ protein in osteosarcoma tissues was higher than that in adjacent tissues, and the expression of PTEN protein in osteosarcoma tissues was lower. The experimental results at both gene and protein levels have proved the NF- $\mathrm{B}$ and PTEN expression was negatively correlated, suggesting these two molecules can act as potential biomarkers for the clinical detection of osteosarcoma.

The patients with osteosarcoma were follow-up for fiveyears. The results showed that the 5-year survival rate was higher in patients with $\mathrm{NF}-\kappa \mathrm{B}$ negative expression and those with PTEN positive expression. The difference was statistically significant. The result indicates that combining with detection of NF- $\kappa \mathrm{B}$ and PTEN expression can better assess clinically the prognosis of patients with osteosarcoma, which provides a new direction for the clinical treatment of osteosarcoma.

\section{Acknowledgements}

This study was supported by the Natural Science Program of Science and Technology commission of Tianjin (no. 043609011) and the Launching fund project of Youth Doctor from
Logistics College of Chinese People's Armed Police Forces (no. WYB201109).

\section{References}

1. Gao KT and Lian D: Long non-coding RNA MALAT1 is an independent prognostic factor of osteosarcoma. Eur Rev Med Pharmacol Sci 20: 3561-3565, 2016.

2. Sun XZ, Liao Y and Zhou CM: NKD2 a novel marker to study the progression of osteosarcoma development. Eur Rev Med Pharmacol Sci 20: 2799-2804, 2016.

3. Yan M, Ni J, Song D, Ding M and Huang J: Activation of unfolded protein response protects osteosarcoma cells from cisplatin-induced apoptosis through NF- $\mathrm{KB}$ pathway. Int J Clin Exp Pathol 8: 10204-10215, 2015.

4. Xia M, Tong JH, Ji NN, Duan ML, Tan YH and Xu JG: Tramadol regulates proliferation, migration and invasion via PTEN/PI3K/AKT signaling in lung adenocarcinoma cells. Eur Rev Med Pharmacol Sci 20: 2573-2580, 2016.

5. Ersahin A, Acet M, Acet T and Yavuz Y: Disturbed endometrial NF- $\kappa B$ expression in women with recurrent implantation failure. Eur Rev Med Pharmacol Sci 20: 5037-5040, 2016.

6. Wang L, Yang L, Lu Y, Chen Y, Liu T, Peng Y, Zhou Y, Cao Y, Bi Z, Liu T, et al: Osthole induces cell cycle arrest and inhibits migration and invasion via PTEN/Akt pathways in osteosarcoma. Cell Physiol Biochem 38: 2173-2182, 2016.

7. Ma T, Guo CJ, Zhao X, Wu L, Sun SX and Jin QH: The effect of curcumin on NF- $\kappa \mathrm{B}$ expression in rat with lumbar intervertebral disc degeneration. Eur Rev Med Pharmacol Sci 19: 1305-1314, 2015.

8. Shen L, Chen XD and Zhang YH: MicroRNA-128 promotes proliferation in osteosarcoma cells by downregulating PTEN. Tumour Biol 35: 2069-2074, 2014.

9. Pang PC, Shi XY, Huang WL and Sun K: miR-497 as a potential serum biomarker for the diagnosis and prognosis of osteosarcoma. Eur Rev Med Pharmacol Sci 20: 3765-3769, 2016.

10. Ju L, Zhou YM and Yang GS: Up-regulation of long non-coding RNA BCAR4 predicts a poor prognosis in patients with osteosarcoma, and promotes cell invasion and metastasis. Eur Rev Med Pharmacol Sci 20: 4445-4451, 2016.

11. Sun H, Zheng X, Wang Q, Yan J, Li D, Zhou Y, Lin Y, Zhang L and Wang $\mathrm{X}$ : Concurrent blockade of NF- $\mathrm{BB}$ and Akt pathways potentiates cisplatin's antitumor activity in vivo. Anticancer Drugs 23: 1039-1046, 2012.

12. Mongre RK, Sodhi SS, Ghosh M, Kim JH, Kim N, Sharma N and Jeong DK: A new paradigm to mitigate osteosarcoma by regulation of microRNAs and suppression of the NF- $\kappa \mathrm{B}$ signaling cascade. Dev Reprod 18: 197-212, 2014.

13. Liu CJ, Yu KL, Liu GL and Tian DH: MiR 214 promotes osteosarcoma tumor growth and metastasis by decreasing the expression of PTEN. Mol Med Rep 12: 6261-6266, 2015.

14. Kawano M, Tanaka K, Itonaga I, Ikeda S, Iwasaki T and Tsumura H: microRNA-93 promotes cell proliferation via targeting of PTEN in osteosarcoma cells. J Exp Clin Cancer Res 34: 76, 2015.

15. Shang ZM, Tang JD, Jiang QQ, Guo A, Zhang N, Gao ZX and Ji WS: Role of $\Delta 133 \mathrm{p} 53$ in tumor necrosis factor-induced survival of p53 functions in MKN45 gastric cancer cell line. Eur Rev Med Pharmacol Sci 19: 2416-2422, 2015.

16. Tian Z, Guo B, Yu M, Wang C, Zhang H, Liang Q, Jiang K and Cao L: Upregulation of micro-ribonucleic acid-128 cooperating with downregulation of PTEN confers metastatic potential and unfavorable prognosis in patients with primary osteosarcoma. Onco Targets Ther 7: 1601-1608, 2014.

17. Hu Y, Xu S, Jin W, Yi Q and Wei W: Effect of the PTEN gene on adhesion, invasion and metastasis of osteosarcoma cells. Oncol Rep 32: 1741-1747, 2014.

18. Song D, Ni J, Xie H, Ding M and Wang J: DNA demethylation in the PTEN gene promoter induced by 5 -azacytidine activates PTEN expression in the MG-63 human osteosarcoma cell line. Exp Ther Med 7: 1071-1076, 2014.

19. Loftus JP, Cavatorta D, Bushey JJ, Levine CB, Sevier CS and Wakshlag JJ: The 5-lipoxygenase inhibitor tepoxalin induces oxidative damage and altered PTEN status prior to apoptosis in canine osteosarcoma cell lines. Vet Comp Oncol 14: e17-e30, 2016.

20. Lu Y, Li F, Xu T and Sun J: Tetrandrine prevents multidrug resistance in the osteosarcoma cell line, U-2OS, by preventing Pgp overexpression through the inhibition of NF- $\mathrm{kB}$ signaling. Int J Mol Med 39: 993-1000, 2017. 